\title{
External Factors Affecting Second Language Motivation: The Role of Teacher Burnout and Family Influence
}

\section{Soroor Rostami}

MA student of TEFL, Imam Reza International University, Mashhad, Iran

\author{
Afsaneh Ghanizadeh* \\ Assistant professor of TEFL, Imam Reza International University, Mashhad, Iran \\ Behzad Ghonsooly \\ Professor of Applied Linguistics, Ferdowsi University, Mashhad, Iran
}

Received 10 May 2015; revised 19 July 2015; accepted 10 August 2015

\begin{abstract}
Motivation can be conceptualized as a dynamic process which is a key contributor to mastering a second language. This study used the L2Motivational Self System as the basis for a conceptual framework for studying the effects of external factors on learners' motivation. In particular, the role of teachers and parents was studied as the external facets of predicting learners' motivation. One hundred and twenty EFL teachers along with 1,270 of their students participated in the study. To measure motivation, the Persian version of Dörnyei's L2 Motivation Self-System Scale was utilized. Three key components of the scale, namely, criterion measure, attitudes to L2 learning, and instrumentality promotion were employed in measuring motivation. To assess the role of family in motivating learners, another subscale of Dörnyei's questionnaire, i.e., family influence was used. To gauge teacher burnout, the educator version of the Maslach burnout inventory (MBI-ES) was used. Structural equation modeling (SEM) was run to analyze the causal

*Corresponding author: English Department, Imam Reza International University, Daneshgah St., Mashhad, Iran.

Email address: a,ghanizadeh@imamreza.ac.ir
\end{abstract}


relationships among the variables. The results revealed that teacher burnout negatively influenced learners' criterion measure and their attitudes to learning English. However, the path leading from teacher burnout to instrumentality promotion was not significant. Furthermore, three direct, positive, and significant paths leading from family influence to learners' criterion measure, instrumentality promotion, and attitudes to learning English were detected. Finally, findings are discussed with reference to the context of Iran.

Keywords: Attitudes to L2 learning; Criterion measure; Family influence; L2 motivation; Instrumentality promotion; Teacher burnout; SEM

\section{Introduction}

Motivation as a key contributor to mastering L2 is believed to encompass all other factors involved in L2 learning. It can be defined as "a dynamic, continuously changing resultant of a variety of internal and external forces" (Dörnyei, 2005, p.90). A recent theory in the field of L2 motivation is the L2 Motivational Self System proposed by Dörnyei (2005, 2009). Dörnyei's L2 Motivational Self System model suggests that motivation is based on three main facets: the Ought-to L2 self, the Ideal L2 self, and the L2 learning experience (Dörnyei, 2005). The ought-to L2 self refers to the attributes that a person believes ought to possess as a result of various duties, responsibilities, or obligations in order to meet expectations or avoid negative outcomes. The Ideal L2 Self refers to the characteristics that someone would ideally like to possess (Dörnyei, 2010). In fact, it is the ideal image of the L2 user one wishes to be in the future. L2 learning experience refers to the situational and environmental aspects of the language learning process as well as one's subjective learning experience (Dörnyei, 2005).

Students' motivation for EFL learning and their performance have been found to be affected by a variety of intrinsic and extrinsic factors in different circumstances (Ghanizadeh \& Rostami, 2015). According to Williams and Burden (1997), the reason why people opt for certain ways is inherent in their motivational disposition. Intrinsic motivation has been defined as the learners' inner reasons for learning. It exists within the individual and is conducted by a fondness of or enjoyment in the task itself (Ryan \& Deci, 2000). Some of the intrinsic reasons to operate on EFL learning are interest, curiosity, independent mastery, and internal criteria for success (Erdoğan \& Tunaz, 2012). On the other hand, extrinsic motivation comes from influences outside of the individual and is described as the performance of an 
activity in order to access a desired outcome (Ryan \& Deci, 2000). Common extrinsic motivations are parents, teachers, friends, rewards, grades, learning environment, and the threat of punishment. According to Brophy (1987), motivation for learning is stimulated most directly through communication of expectations, modeling, and direct education or socialization by significant others (in particular, teachers and parents). Inasmuch as parents and teachers are two main external sources of motivation which influence students' motivation and their performance, the present study will investigate the role of teacher burnout and family influence in a number of the motivational factors of Dörnyei's L2 Motivational Self System model.

\section{Teacher Burnout}

Keller (1987, p.6) stated that "seldom do the arguments about the boundaries of teacher's responsibilities or whether teaching is an art or science become more animated than when discussing the motivation of the students". The characteristic of a language educator as an essential motivating factor has numerous effects on students' motivational tendency and success of learning. Teacher's beliefs about learning will undoubtedly be reflected in his/her teaching and the perceptions of the pupils will be shaped in accordance with these beliefs. Hence, while investigating the sources of demotivation among students, we cannot deny teacher element (Erdoğan \& Tunaz, 2012). To a great degree, students expect to learn if their educators expect them to learn (Stipek, 1988). In a recent study, Ghanizadeh and Jahedizadeh (2015b) identified six de-motivators in language classes, namely teachers, characteristics of classes, experiences of failure, class environment, class materials, and lack of interest. More specifically, the results of structural equation modeling demonstrated the influence of teachers on learners' burnout. They concluded that teachers play an important role in motivating students given that learners look at their teachers for reinforcement and approval.

One of the professions prone to high levels of burnout is teaching (Maslach, 1982). Teacher burnout is defined as "a syndrome of emotional exhaustion, depersonalization, and reduced personal accomplishment" that can occur among individuals who work with people in some capacity (Maslach, 1982, p.3). Emotional exhaustion, as a key aspect of the burnout syndrome occurs when teachers feel their emotional resources being depleted and overextended by contact 
with other people, particularly their students. Another aspect of the burnout syndrome is depersonalization which occurs when teachers develop impersonal and even dehumanized perception of others. The third attribute of the burnout syndrome, referring to a decline in professional competence and effectiveness is reduced personal accomplishment. Related symptoms of teacher burnout include hopelessness, depression, anxiety, fatigue, frustration, powerlessness, failure, and inability (Pines, 1982).

Despite the devastating effects of teacher burnout on learners' performance, empirical research conducted on the topic has been scarce in the field of language learning. Most of the existing research focuses on the burnout of teachers teaching a general course (Brenninkmeijer, Vanyperen, \& Buunk, 2001; Brouwers \& Tomic, 2000; Doménech \& Gomez, 2010;;; Lim \& Leo, 2014; Mukundan, 2011)).These studies delved into teacher burnout from a host of aspects and perspectives, including factors affecting depersonalization, emotional exhaustion, and reduced personal accomplishment of burnout (Chang, 2009; Doménech \& Gomez, 2010; Dorman, 2003), and its deleterious effects on the stressed teacher and the institution, and coping strategies (Dillon \& Tanner, 1995; Ray, 1991; Ray \& Miller, 1991; Starnaman \& Miller, 1992). To the researchers' best knowledge, the only research examining the impacts of teacher burnout syndrome on students' motivation and affective learning is the study conducted by Zhang and Saap (2008). They investigated the role of teacher burnout in students' state motivation and assessed the moderating effect of teacher nonverbal immediacy. The results showed that teacher burnout adversely impacted students' affective learning and their state motivation, and teacher nonverbal immediacy reduced the negative effect of teacher burnout on students. Moreover, students reported the lowest motivation and affective learning with high burnout and low immediacy teachers, and the highest motivation and affective learning with low burnout and high immediacy teachers.

\section{Family Influence}

Family is the foundation of each person's character, in the same way that roots are for tree. Family involvement is a concept that can include various activities. It can range from an impersonal visit to school once a year to frequent parent-teacher consultations. Thus, it can be placed on a continuum ranging from very low to very active involvement (Brito \& Waller, 1994). It goes without saying that families play a determinant role in students' educational achievement and endeavors. One of 
the sub-factors of Dörnyei's L2 Motivational Self System model is family influence. It examines active and passive parental roles and highlights the impact from family background (Dörnyei, 2005).

Furthermore, it is undeniable that family is a key factor in understanding the affective basis of instructed SLA. Accordingly, it has significant bearing on the students' motivational status and, generally, on their learning achievement. In spite of its importance, the "family influence" concept is still vague and its outcomes are unclear.

Several studies have indicated the positive effect of family involvement on components of children's education such as cognitive and social skills or achievement, behavior and attitude, daily attendance, motivation, and confidence (e.g. Cotton \& Wikelund, 2001; Epstein, 2001; Hoover-Dempsey \& Sandler, 1995; Reutzel \& Cooter, 1996; Sheldon, 2003; Wanke, 2008). According to Epstein (2001), children mature via three overlapping spheres of influence: community, school, and family. Students who have been supported by their parents at home show better performance at school, whereas learners lacking support are struggling. Besides, Reutzel and Cooter (1996) found that positive effects of parental involvement tended to increase when choices are provided to the parents. The schools that offer a variety of ways for parents to get involved have a substantial influence on students' achievement. By giving parents various methods or activities to incorporate in their children's lives, their willingness will increase. The enhancement of parental involvement has demonstrated a consistent and positive relationship in students' development and achievement in school (Wanke, 2008).

On the other hand, several studies reported a negative relationship between children's school success and parent/school contact (Desimone, 1999; Steinberg, Lamborn, Dornbusch, \& Darling, 1992; Taylor, 1996). Desimone (1999) analyzed a nationally representative sample of nearly 25,000 eighth graders and found negative associations between parents' contact with the school regarding academic matters and students' achievement. Rigsby, Stull, and Morse-Kelly (1995) suggested that one explanation behind this perplexing result is that parents may become involved with young students' schooling when the youths experience either behavioral problems or poor grades. 
Taken together, the role of constructs discussed above- learners' motivation, teacher burnout, and family influence-in effective teaching and learning has conclusively been demonstrated by educational researchers. The present study aimed at verifying the impact of these external forces on learners' motivation within a single framework.

\section{Purpose of the study}

The main purpose of this study is to investigate the role of two external factors (teacher burnout and family influence) in learners' motivation. Out of 10 subfactors of Dörnyei's L2 Motivational Self System Model, 4 factors were employed to inform the present research. The factors and their sample items are as follows (Taguchi, Magid, \& Papi, 2009):

(1) Criterion measures examining the learners' intended efforts toward learning English (e.g., I would like to spend lots of time studying English and I would like to concentrate on studying English more than any other topic).

(2) Instrumentality-promotion measuring the regulation of personal goals to become successful such as attaining high proficiency in English in order to make more money or find a better job (e.g., Studying English can be important to me because I think it will someday be useful in getting a good job and/or making money and Studying English is important to me because English proficiency is necessary for promotion in the future).

(3) Attitudes to learning English assessing situation-specific motives related to the immediate learning environment and experience (e.g., Do you like the atmosphere of your English classes? and Do you always look forward to English classes?).

(4) Family influence examining active and passive parental roles (e.g., My parents/family believes that I must study English to be an educated person and Studying English is important to me in order to bring honors to my family).

Given the above-mentioned literature on learners' motivation, teacher burnout, and family influence, the following research questions were posed:

1. Is there any significant relationship between EFL teacher's burnout and learner's motivation? 
a. Is there any significant relationship between EFL teacher's burnout and learner's criterion measures?

b. Is there any significant relationship between EFL teacher's burnout and learner's instrumentality-promotion?

c. Is there any significant relationship between EFL teacher's burnout and learner's attitudes to learning English?

2. Is there any significant relationship between family influence and learner's motivation?

a. Is there any significant relationship between family influence and learner's criterion measures?

b. Is there any significant relationship between family influence and learner's instrumentality-promotion?

c. Is there any significant relationship between family influence and learner's attitudes to learning English?

\section{Methodology}

\section{Participants}

The participants of the study comprised 120 EFL teachers along with 1,270 of their students who were selected from different private language institutes and high schools in Mashhad. Their selection was based on convenience sampling and the participation was entirely voluntary. In order to make our results robust, we attempted to collect as large a sample as we could in each context.

\section{Instruments}

\section{L2 Motivational Self System questionnaire}

The current study employed an English learner questionnaire to measure learner's motivation and family influence. It was designed and validated by the School of English Studies of the University of Nottingham UK. The Persian version of the questionnaire translated and validated by Papi (2010) was utilized in the present study. This questionnaire is composed of two major parts: the first part consists of 25 items measuring the learners' attitudes and motivation concerning English learning on a 6-point Likert scale ranging from "strongly disagree" to "strongly 
agree" and the second part consists of 10 questions about the learners' background information (e.g. gender, nationality, age, overseas experience, and self-rated English proficiency levels). Table 1 displays the reliability indices (measured via Cronbach's alpha) of the questionnaire in the original study (Papi, 2010) and in the present study.

Table 1

The Reliability Indices of the L2 Motivational Self System Scale Maslach burnout inventory (MBI-ES)

\begin{tabular}{lccc}
\hline Factor & Item No. & $\begin{array}{c}\text { Reliability in the } \\
\text { original study }\end{array}$ & $\begin{array}{c}\text { Reliability in } \\
\text { the present } \\
\text { study }\end{array}$ \\
\hline Criterion measures & $8,16,24,32,40,50$ & 0.79 & 0.90 \\
\hline Instru- promotion & $3,12,20,28,37,45$ & 0.67 & 0.98 \\
\hline Attitudes to L2 L & $54,59,63,67,71,75$ & 0.82 & 0.98 \\
\hline Family influence & $2,11,19,27,35,44$ & 0.69 & 0.99 \\
\hline
\end{tabular}

The current study employed the educator version of the Maslach burnout inventory (MBI-ES) developed by Maslach, Jackson, and Leiter (1996) to measure teacher burnout. The scale comprises 22 self-report items measured on three subscales. Nine items measure emotional exhaustion (e.g., "I feel used up at the end of the day"), five items measure depersonalization (e.g., "I worry that this job is hardening me emotionally"), and eight items measure personal accomplishment (e.g., "I have accomplished many worthwhile things in this job"). The frequency of burnout symptoms is measured on a seven-point rating scale, ranging from never (0) to every day (6). Higher emotional exhaustion and desensitization subdimensions and lower personal accomplishment sub-dimensions cause high burnout status. The inventory enjoys high reliability and validity indices (Hastings $\&$ Bham, 2003). Table 2 displays the reliability indices (measured via Cronbach's alpha) of the questionnaire in the original study (Maslach, Jackson, \& Leiter, 1996) and the present study. 
Table 2

The Reliability Indices of the Maslach Burnout Inventory Scale

\begin{tabular}{lccc}
\hline Factor & Item No. & $\begin{array}{c}\text { Reliability in } \\
\text { the original } \\
\text { study }\end{array}$ & $\begin{array}{c}\text { Reliability in } \\
\text { the present } \\
\text { study }\end{array}$ \\
\hline Emotional exhaustion & $\begin{array}{c}1,4,9,10,15,16,18, \\
20,22\end{array}$ & 0.76 & 0.98 \\
\hline $\begin{array}{l}\text { Reduced } \\
\text { accomplishment }\end{array}$ & $3,6,7,12,13,17,19$, & 0.73 & 0.98 \\
\hline Depersonalization & 21 & 0.63 & 0.90 \\
\hline
\end{tabular}

\section{Procedure}

The data collection of this study took place in April and May 2014. After a brief explanation of the purpose of the research, all teachers received the Maslach burnout inventory (MBI-ES) scale. Simultaneously, all or a number of the students of every teacher received the Persian version of L2 Motivational Self System questionnaire. To collect reliable data, the researchers explained the purpose of completing the questionnaire and asked them not to write a name on them. They just were required to provide demographic information such as, gender, age, teaching experience and educational level. In order to analyze the data in this study, the responses that were obtained from the questionnaires were tabulated and analyzed using SPSS software. A structural equation modeling (SEM) analysis was performed to examine the cause-effect relationship between learners' motivation, teacher burnout, and family influence variables.

\section{Results}

Descriptive statistics of teacher burnout, family influence, and different components of motivation are presented in Table 3. As table 3 demonstrates, 
among the three components of motivation, instrumentality promotion receives the highest mean $(M=28.61, S D=5.52)$ and Criterion measures obtains the lowest mean $(M=26.17, S D=6.28)$. Moreover, the mean scores of Teacher Burnout and Family Influence are 69 and 25.99, respectively.

Table 3

Descriptive Statistics of Teacher Burnout, Family Influence, and Different Components of Motivation

\begin{tabular}{lcccc}
\hline & Min & Max & Mean & SD \\
\hline & & & & \\
Teacher Burnout & 24 & 133 & 69.56 & 2.81 \\
Family Influence & 8.36 & 35.50 & 25.99 & 8.39 \\
Criterion measures & 13.64 & 34.82 & 26.17 & 6.28 \\
instrumentality - & 17.89 & 35.62 & 28.61 & 5.52 \\
promotion & & & & \\
Attitudes to L2 L & 17.73 & 34.55 & 27.21 & 4.69 \\
\hline
\end{tabular}

In order to examine the structural relationships, the proposed model was tested using Amos 20 statistical package. As Gary, Ockey, and Choi (2015) emphasized, reports of SEM should include appropriate model fit indices to be validly interpreted. According to $\mathrm{Hu}$ and Bentler (1998), model fit is generally evaluated by examining multiple fit indices, such as the root mean square error of approximation (RMSEA), the comparative fit index (CFI), the chi-square $\left(X^{2}\right)$, and the critical ratio $\left(X^{2} / d f\right)$. RMSEA values of .06 or lower are indicative of a good fit. CFI values of greater than .95 have been used to indicate a good fit to the data. Greater CFI values indicates a better fit and- therefore, numbers closer to 1.0 indicate better fit to the data. Besides, the chi-square/df ratio should be less than 3 to indicate a good fit (Hu \& Bentler, 1999).

Figure 1 represents the schematic relationships among teacher burnout, family influence, and different components of motivation. As it can be seen in figure 1, the error terms of C8 and C32, C16 and C24, i12 and i20, a67 and a71, a54 and $\mathrm{a} 59$, and of $\mathrm{f} 2$ and $\mathrm{f} 11$ were allowed to covary because they shared a similar item content that could lead to potential error covariance. All the fit indices, RMSEA (.06), CFI (.97), and the chi-square/df ratio (1.56), lie within the acceptable fit 
thresholds based on $\mathrm{Hu}$ and Bentler (1999). Hence, it can be concluded that the proposed model had a good fit with the empirical data.

To check the strengths of the causal relationships among the components, the standardized estimates were examined. As indicated in figure 1, an estimate is displayed on each path. This standardized estimate is the standardized coefficient or beta coefficients $(\beta)$ resulting from an analysis carried out on independent variables that have been standardized. It explains the predictive power of the independent variable and the effect size. The closer the magnitude to 1.0, the higher the correlation and the greater the predictive power of the variable is. The results are as follows: Teacher Burnout/ Criterion measure $(\beta=-.20)$, Teacher Burnout/ Instrumentality promotion $(\beta=.04)$, Teacher Burnout/ Attitudes to learning English $(\beta=-.35)$, Family influence/ Criterion measure $(\beta=.86)$, Family influencel Instrumentality promotion $(\beta=.94)$, and Family influencel Attitudes to learning English $(\beta=.72)$. However, the association between Teacher burnout and Instrumentality promotion was not significant $(p=.03)$. In sum, among the three motivational factors, Attitudes to language learning is highly predicted by teacher burnout followed by criterion measure. Family influence predicts all three motivational factors with instrumentality promotion undergoing the highest influence. 


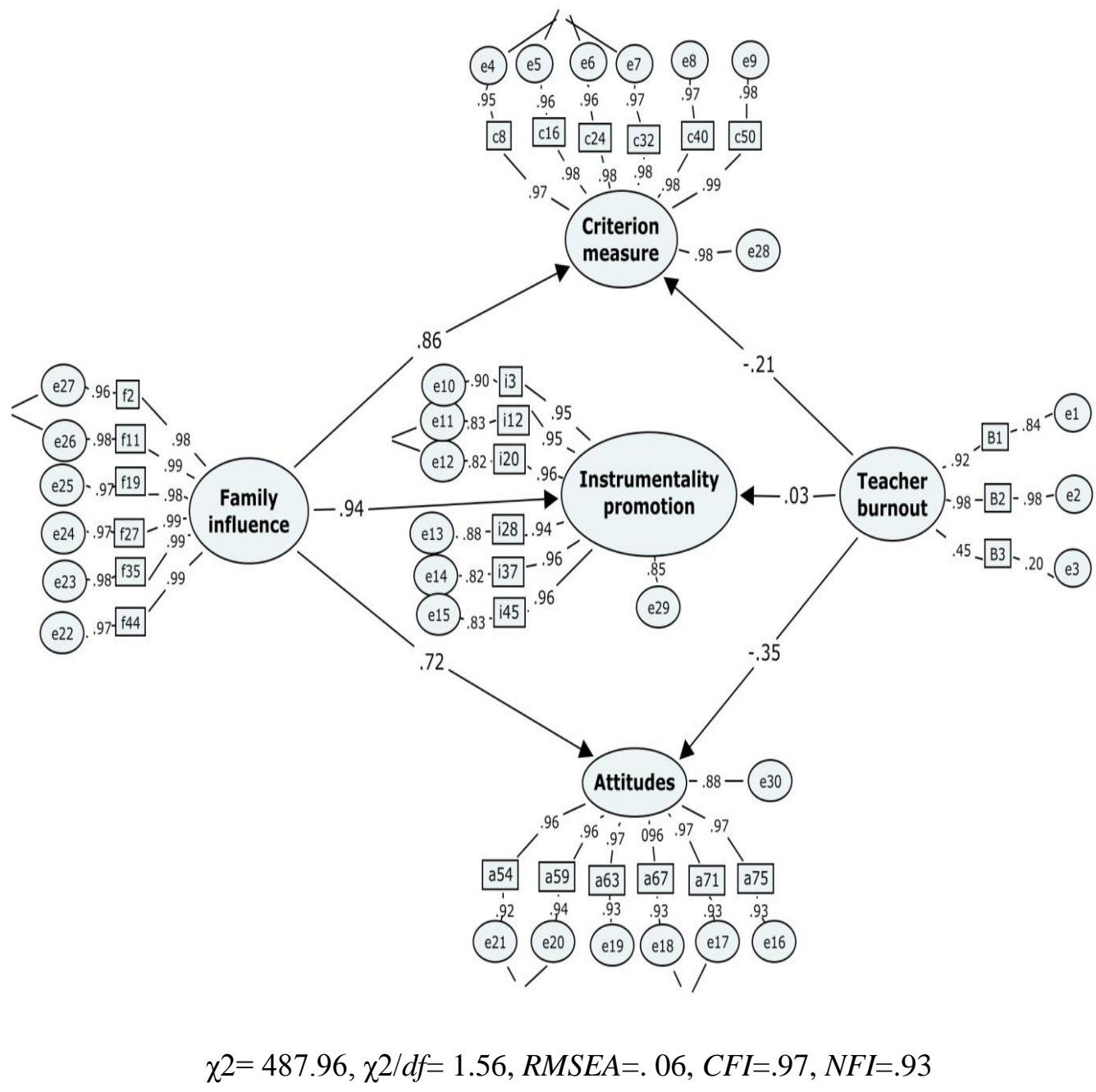

\section{Figure 1:}

The schematic representation of the association between variables under study 
According to Gary, Ockey, and Choi, (2015), "a correlation or covariance matrix of all observed variables, which was used for the actual analysis, should be provided, so consumers of the research can attempt to replicate the findings" (p.309). Therefore, table 4 is provided to show the correlation coefficients among teacher burnout and different components of motivation. As table 4 demonstrates, all the motivational factors negatively correlated with teacher burnout. The highest correlation is observed between Teacher burnout and Attitudes to learning English $(r=-.605, p<0.05)$. The lowest correlation was obtained between Teacher burnout and Instrumentality promotion $(r=-.414, p<0.05)$. (Insert Table 4$)$

\section{Table 4}

The Correlation Coefficients among Teacher Burnout and Different Components of Motivation

\begin{tabular}{lcccc}
\hline & $\mathbf{1}$ & $\mathbf{2}$ & $\mathbf{3}$ & $\mathbf{4}$ \\
\hline 1. Burnout & 1.00 & & & \\
2. CRI & $-.589^{* *}$ & 1.00 & & \\
3. IP & $-.411^{* *}$ & $.886^{* *}$ & 1.00 & \\
4. ALE & $-.654^{* *}$ & $.942^{* *}$ & $.824^{* *}$ & 1.00 \\
\hline
\end{tabular}

Table 5 represents the correlation coefficients among family influence and different components of motivation. As table 5 demonstrates, all the motivational factors positively correlated with family influence. The highest correlation is observed between Family influence and Criterion measure $(r=.956, p<0.05)$. The lowest correlation was obtained between Attitudes to learning English and Family influence $(r=.880, p<0.05)$. 


\section{Table 5}

The Correlation Coefficients among Family Influence and Different Components of Motivation

\begin{tabular}{|c|c|c|c|c|}
\hline & 1 & 2 & 3 & 4 \\
\hline 1. FI & 1.00 & & & \\
\hline 2. CRI & $.956 * *$ & 1.00 & & \\
\hline 3. IP & $.913 * *$ & $.886^{* *}$ & 1.00 & \\
\hline 4. ALE & $.880 * *$ & $.942 * *$ & $.824 * *$ & 1.00 \\
\hline
\end{tabular}

\section{Discussion}

The current study sought to investigate the role of two external factors (teacher burnout and family influence) in learners' motivation among Iranian EFL students. In attaining the objectives of the study, structural equation modeling (SEM) was employed to examine the causal relationships among the variables. Based on the results of SEM, it can be concluded that the proposed model demonstrated a good fit with the empirical data verifying the proposed interrelationships among teacher burnout, family influence, and different components of motivation. To achieve a clear picture of the associations, each path is consecutively discussed below.

The results demonstrated the negative impact of teacher burnout on learners' criterion measure. Criterion measure assesses the learners' intentional efforts toward learning English. In other words, it seeks to explore to what extent learners like to spend time studying English. The findings showed that teacher burnout had a negative effect on learners' criterion measure, justifying the plausibility of considering the role of teachers in shaping learners' motivation to spend time studying English. This finding is in line with the research evidence obtained in Kotherja's study (2003) indicating that if teachers are motivated and satisfied in their job, the students will get enduring motivation. Contemplating upon the burnout consequences clearly reveals that one of the most frequent ramifications of burnout is the decline in job interest and commitment (Ghanizadeh \& Jahedizadeh, 2015a). Accordingly, when emotionally exhausted, teachers are not actively and enthusiastically involved in organizing classroom time and in devising tasks and activities, and when they do not invest energy and creativity in their endeavors, this 
mood would normally be reflected in the classroom and depreciate students' efforts, attitudes, and motivation. Furthermore, when teachers develop impersonal perception of students (as one of the aspects of burnout syndrome), they do not normally pay enough attention to their students' concerns and attitudes thereby impinging on learners' sense of attachment to the classroom as well as their motivation to learn.

The results also revealed that path leading from teacher burnout to instrumentality promotion was not significant. Instrumentality promotion measures the personal goal-setting to become successful in affairs associated with high proficiency in English. This should not be surprising if Iranian EFL context is taken into consideration. In Iran, the main concern of teachers -in particular teachers in official settings - is to make learners ready to pass the course and enter universities, not to get a good job or to be proficient for promotion in the future. Therefore, it seems plausible that in these contexts, teachers do not typically play a prominent role in molding learners' personal goals and preferences.

Furthermore, teacher burnout had a negative effect on learners' attitudes to learning English. Attitudes to learning English measure learners' situation-specific motives related to immediate learning environment and experience. This finding corroborates previous research (Blasé, 1982; Byrne, 1991; Dörnyei \& Csizer, 1998; Evers, Tomic \& Brouwers, 2004; Grayson, 2006; Schonfeld, 2001). Since teachers are role models, their psychological states affect the psychological state of the students around them as well (Grayson, 2006). Besides, as Dörnyei and Csizer (1998) maintained, teachers' behavior is a powerful tool in shaping and influencing students' motivational disposition. Moreover, Ghanizadeh and Royaei (2015) reported that teacher burnout causes less involvement and motivation on the part of students in their classrooms. Therefore, teachers play a crucial role in creating a classroom climate which fosters students' positive attitudes to language learning as well as their emotional well-being.

Three direct, positive, and significant paths leading from family influence to learners' criterion measure, instrumentality promotion, and attitudes to learning English indicate that the role of family in motivating children is still strong in Iran. These findings imply that parents in Iran view English learning as a venue opening up better educational opportunities inside and outside the country or offering the 
prospect of living abroad. Besides, as Taguchi, Magid, and Papi (2009) mentioned, the growing trend of language learning among Iranian people these days is due to their desire "to enter prestigious universities and thereby proceed to the highest levels of education and strata in their society" (p. 71). Since in Iran, family has a key role in decision making for their children, parents can readily motivate their children to learn English and bring honor to the family.

\section{Conclusion}

The present study aimed to address the importance of teacher and family in fostering motivation for learning English as a foreign language. Taken together, the results of this research yielded a number of pedagogical implications. First, given that Iran is regarded as a family-centered country, giving parents a voice, providing them with information, and encouraging parental partnerships with school can have substantial influence on shaping learners' academic mindset and motivation. Accordingly, education stakeholders should adopt strategies to enhance parental involvement in their children's schooling and hold teacher-parent meetings to make parents aware of their crucial roles in their children's education. Second, the impact of teachers' status and their emotions on affecting learners' motivation should not be neglected. It is vital that prior to any attempt to create any kind of motivation, teachers regularly probe their emotional states and perceptions (Ghanizadeh \& Royaei, 2015). To this end, teachers should be aware of deteriorating effects of burnout on not only their professional lives, but also on their students. Hence, if teachers utilize some strategies to diminish burnout syndrome, this will in turn lead to a change in students' thought patterns and inspirations. Diefendorff, Richard, and Yang (2008, p. 503) put forward the following emotion regulation strategies which might help teachers deplete burnout: 1) Seek out individuals who make you feel good; 2) Keep yourself busy working on other things; 3) Do something enjoyable to improve your mood; 4) Try to solve the problem; 5) Find humor in the situation; 6) Think about how the other person feels; 7) Consider how things could be worse; 8) Pretend you are in a good mood; 9) Turn your attention to something that doesn't bother you, and 10) Remind yourself that you cannot control everything.

Accordingly, educational policy makers are recommended to present intervention programs to make teachers familiar with the syndrome and help them mitigate burnout and stress. Such programs can be differentiated based on the orientation and intention of the designed treatment: (a) direct action programs dealing directly with the causes of burnout, and (b) palliative programs involving 
indirect treatment of burnout, focusing on techniques for alleviating tension or fatigue. These intervention programs should take into account the potential antecedents of burnout.

Previous research has indicated that emotional exhaustion is the prime predictor of teacher burnout and is directly linked to negative exchanges with students and teachers' personal experiences and characteristic (Ghanizadeh \& Jahedizadeh, 2015a). Teacher education programs, thus, are recommended to structure regulation strategies programs with a specific focus on the emotional side of teachers' profession.

At the organizational levels, the strategies might include reducing degree of polarization in the classroom, reducing number of pupils per class, and changing teacher's work plan or teaching plan. Additionally, treatment of symptoms of stress for the organizational level could encompass creating a supportive atmosphere in the school, opening channels of communication, increasing involvement in decision making, and developing a positive and open organizational climate (Ghanizadeh \& Jahedizadeh, 2015a).

\section{Notes on Contributors}

Soroor Rostami is an M.A student of TEFL (teaching English as a foreign language) at Imam Reza International University of Mashhad. She has taught English in private Institutes for about 6 years. She has published several articles in scientific Journals. Her major research interests are psychological areas, such as learners' motivation and teacher burnout.

Afsaneh Ghanizadeh is an assistant professor at Imam Reza International University, Mashhad, Iran. She received her PhD in TEFL from Ferdowsi University of Mashhad. She has published over 50 papers in research scientific journals and about 12 papers in ISI or Scopus-indexed journals. Her research interests include psycholinguistics and psychology of language teaching and learning. 
Behzad Ghonsooly is a professor of Applied Linguistics at Ferdowsi University of Mashhad, Iran. He received his PhD from Edinburgh University, UK. He has published widely in the field. His main research interests include language testing, English for specific purposes, and psycholinguistics.

\section{References}

Ann Wanke, A. (2008). Parental involvement in children's education. Unpublished MA thesis. The State University of New York at Potsdam.

Blasé, J.J. (1982). A social-psychological grounded theory of teacher stress and burnout. Educational Administration Quarterly, 18(4), 93-113.

Brenninkmeijer, V., Vanyperen, N. W., \& Buunk, B. P. (2001). I am not a better teacher, but others are doing worse: Burnout and perceptions of superiority among teachers. Social Psychology of Education, 4, 259-274.

Brito, J., \& Waller, H. (1994). Partnership at a price? In R. Merttens, D. Mayers, A. Brown \& J. Vass (Eds), Ruling the Margins: Problematizing Parental Involvement (pp. 157-166). London: Institute of Education, University of London.

Brophy, J. (1987). Synthesis of research on strategies for motivating students to learn. Educational Leadership, 45, 40-48.

Brouwers, A., \& Tomic, W. (2000). A longitudinal study of teacher burnout and perceived self-efficacy in classroom management. Teaching and Teacher Education, 16(2):239-253.

Byrne, B. M. (1991). Burnout: Investigating the impact of background variables for elementary, intermediate, secondary and university educators. Teaching and Teacher Education, 7(2), 197-209.

Chang, M. (2009). An appraisal perspective of teacher burnout: Examining the emotional work of teachers. Educational Psychological Review, 21, 193218.

Cotton, K., \&. Wikelund, K. R. (2001). Parent involvement in education. School Improvement Research Series. Portland, OR: Northwest Regional 
Educational Laboratory. Available online at www.nwrel.org/scpd/sirs/3/cu6.html

Desimone, L. (1999). Linking parent involvement with student achievement: Do race and income matter? The Journal of Educational Research, 93(1), 1130 .

Diefendorff, J. M., Richard, E. M., \&Yang, J. (2008). Emotion regulation at work: Linking strategies to affective events and discrete negative emotions. Journal of Vocational Behavior, 73, 498-508.

Dillon, J. F., \& Tanner, G. R. (1995). Dimensions of career burnout among educators. Journalism and Mass Communication Educator, 50, 4-13.

Doménech, F., \& Gómez, A. (2010). Barriers perceived by teachers at work, coping strategies, self-efficacy and burnout. The Spanish Journal of Psychology, 13(2), 637-654.

Dorman, J. (2003). Testing a model for teacher burnout. Australian Journal of Educational and Developmental Psychology, 3, 35-47.

Dörnyei, Z. (2005). The psychology of the language learner: Individual differences in second language acquisition. Mahwah, NJ: Lawrence Erlbaum.

Dörnyei, Z. (2009). The L2 motivational self system. In Z. Dörnyei, \& E. Ushioda (Eds.), Motivation, language identity and the L2 self (pp. 9-42). Bristol: Multilingual Matters.

Dörnyei, Z. (2010). Researching motivation: From integrativeness to the ideal L2 self. In S. Hunston and D. Oakey (Eds.), Introducing Applied Linguistics: Concepts and Skills (pp. 74-83). London: Routledge.

Dörnyei, Z., \& Csizér, K. (1998). Ten commandments for motivating language learners: Results of an empirical study. Language Teaching Research, 2, 203-229. 
Dörnyei, Z., \& Ushioda, E. (2009). Motivation, language identity and the L2 self. Bristol: Multilingual Matters.

Epstein, J. L. (2001). School, family, and community partnerships: Preparing educators and improving schools. Boulder, CO: Westview Press.

Erdoğan, E., \& Tunaz, M. (2012). Determining External and Internal Demotivating Factors among Young Learners at Pozantı Regional Primary Boarding School. Frontiers of Language and Teaching, 3, 147-160.

Evers, W. J. G., Tomic, W., \& Brouwers, A. (2004). Burnout among teachers: Students' and teachers' perceptions compared. School Psychology International, 25 (2), 131-148.

Gary J. Ockey, G. J., \& Choi, I. (2015). Structural equation modeling reporting practices for language assessment. Language Assessment Quarterly, 12(4), 305-319.

Ghanizadeh, A., \& Jahedizadeh, S. (2015a). Teacher burnout: A review of sources and ramifications. British Journal of Education, Society, and Behavioural Sciences, 6(1), 24-39.

Ghanizadeh, A., \& Jahedizadeh, S. (2015b). De-motivators and their association with burnout and language achievement in an Iranian EFL context. Journal of Teaching Language Skills, 7 (3), 1-32.

Ghanizadeh, A., \& Rostami, R. (2015). A Dörnyei-inspired study on second language motivation: A cross-comparison analysis in public and private contexts. Psychological Studies, 60(3), 292-301.

Ghanizadeh, A., \& Royaei, N. (2015). Emotional facet of language teaching: emotion regulation and emotional labor strategies as predictors of teacher burnout. International Journal of Pedagogies and Learning, 10 (2), 139150. DOI: $10.1080 / 22040552.2015 .1113847$.

Grayson, J. L. (2006). An assessment of teacher burnout levels as associated with contextual and diversity factors in rural Appalachian school districts (Unpublished MA thesis). USA: Ohio University.

Hastings, R. P., \& Bham, M. S. (2003). The relationship between student behaviour patterns and teacher burnout. School Psychology International, 24, 115127. 
Hoover-Demsey, K. V., \& Sandler, H. M. (1995). Parent Involvement in Children's Educations: Whey Does It Make a Difference? Teachers College Record, 97, 310-331.

Hu, L., \& Bentler, P. M. (1998). Fit indices in covariance structure modeling: Sensitivity to under-parameterized model misspecification. Psychological Methods, 3, 424-453.

Hu, L., \& Bentler, P. M. (1999). Cutoff criteria for fit indexes in covariance structure analysis: Conventional criteria versus new alternatives. Structural Equation Modeling, 6, 1-55.

Keller, J.M. (1987). Development and use of the ARCS model of instructional design. Journal of Instructional Development, 10 (3), 2-10.

Kotherja, O. (2003). Teachers' motivation importance and Burnout effect in the educational development. Paper presented at the first Albania International Conference on Education (AICE).

Lim, S., \& Leo, S. (2014). The mediating roles of collective teacher efficacy in the relations of teachers perceptions of school organizational climate to their burnout. Teaching and Teacher Education, 44(38), 147-166.

Maslach, C. (1982). Burnout: The cost of caring. Englewood Cliffs, NJ: PrenticeHall.

Maslach, C., Jackson, S. E., \& Leiter, M. P. (1996). Maslach burnout inventory manual (3rd ed.). Palo Alto: Consulting Psychologists Press.

Mukundan, J., \& Ahour, T. (2011). Burnout among female teachers in Malaysia. Journal of International Education Research, 7(3), 25-38.

Papi, M. (2010). The L2 motivational self system, L2 anxiety, and motivated behavior: A structural equation modeling approach. System, 38, 467-479. 
Pines, A. (1982). Helper's motivation and the burnout syndrome. In T. A. Wills (Ed.), Basic processes in helping relationships (pp. 453-475). New York: Academic Press.

Ray, E. B. (1991). The relationship among communication network roles, job stress, and burnout in educational organizations. Communication Quarterly, 39, 91-102.

Ray, E. B., \& Miller, K. I. (1991). The influence of communication structure and social support on job stress and burnout. Management Communication Quarterly, 4, 506-527.

Reutzel, R., \& Cooter, R. (1996). Teaching children to read: From basals to books. Englewood Cliffs, NJ: Prentice-Hall.

Rigsby, L. C., Stull, J. C., \& Morse-Kelly, N. (1995). School performances: Complicating explanatory models by incorporating race and gender(Unpublished MA thesis).Temple University, Philadelphia.

Rostami, S., Ghanizadeh, A., \& Ghapanchi, Z. (2015). A study of contextual precursors of burnout among EFL teachers. International Journal of Research Studies in Psychology, 4 (1), 13-24.

Ryan, R. M., \& Deci, E. L. (2000). Self-determination theory and the facilitation of intrinsic motivation, social development, and well-being. American Psychologist, 55(1): 68-78.

Schonfeld, I. S. (2001). Stress in first-year women teachers: the context of social support and coping. Genetic, Social, and General Psychology Monographs, 127(2), 133-168.

Sheldon, S. B. (2003). Parental involvement in education. In. J. W. Guthrie (Eds), Encyclopedia of Education (pp. 1844-1847). New York: Macmillan Reference USA.

Starnaman, S. M., \& Miller, K. I. (1992). A test of a causal model of communication and burnout in the teaching profession. Communication Education, 41, 40-53. 
Steinberg, L., Lamborn, S., Dornbusch, S., \& Darling, N. (1992). Impact of Parenting Practices on Adolescent Achievement: Authoritative Parenting, School Involvement, and Encouragement to Succeed. Child Development, $63,1266-1281$.

Stipek, D. (1988). Motivation to learn: From theory to practice. Englewood Cliffs, NJ: Prentice Hall.

Taguchi, T., Magid, M., \& Papi, M. (2009). The L2 motivational self system among Japanese, Chinese, and Iranian learners of English: A comparative study. In Z. Dörnyei \& E. Ushioda (Eds.), Motivation, language identity and the L2 self (pp. 66-97). Clevedon, UK: Multilingual Matters.

Taylor, R. D. (1996). Adolescents' perceptions of kinship support and family management practices: Association with adolescent adjustment in African American families. Developmental Psychology, 32(4), 687-695.

Williams, M., \& Burden, R. L. (1997). Psychology for language teachers: A social constructivist approach. Cambridge: Cambridge University Press.

Zhang, Q., \& Sapp, D. (2008). A burning issue in teaching: the impact of perceived teacher burnout and nonverbal immediacy on student motivation and affective learning. Journal of Communication Studies, 1(2), 152-168. 